\title{
Behavioural evaluation of workers exposed to mixtures of organic solvents
}

\author{
N A MAIZLISH, ${ }^{1 *}$ G D LANGOLF, ${ }^{2}$ L W WHITEHEAD,${ }^{3}$ L J FINE, ${ }^{3} \mathrm{~J}$ W ALBERS, ${ }^{4}$ \\ J GOLDBERG, ${ }^{2}$ AND P SMITH ${ }^{5}$
}

From the Department of Epidemiology, ${ }^{1}$ Centre for Ergonomics, ${ }^{2}$ and Department of Environmental and Industrial Health, ${ }^{3}$ University of Michigan, Department of Neurology, ${ }^{4}$ University of Michigan Medical Center, Ann Arbor, MI 48109, and Department of Industrial and Systems Engineering, ${ }^{5}$ Ohio State University, Columbus, $\mathrm{OH} 43210, \mathrm{USA}$

ABSTRACT Reports from Scandinavia have suggested behavioural impairment among long term workers exposed to solvents below regulatory standards. A cross sectional study of behavioural performance was conducted among printers and spray painters exposed to mixtures of organic solvents to replicate the Scandinavian studies and to examine dose-response relationships. Eligible subjects consisted of 640 hourly workers from four midwestern United States companies. Of these, 269 responded to requests to participate and 240 were selected for study based on restrictions for age, sex, education, and other potentially confounding variables. The subjects tested had been employed on average for six years. Each subject completed an occupational history, underwent a medical examination, and completed a battery of behavioural tests. These included the Fitts law psychomotor task, the Stroop colour-word test, the Sternberg short term memory scanning test, the short term memory span test, and the continuous recognition memory test. Solvent exposure for each subject was defined as (1) an exposed or non-exposed category based on a plant industrial hygiene walk-through and (2) the concentration of solvents based on an analysis of full shift personal air samples by gas chromatography. The first definition was used to maintain consistency with Scandinavian studies, but the second was considered to be more accurate. The average full shift solvent concentration was $302 \mathrm{ppm}$ for the printing plant workers and 6-13 ppm for the workers at other plants. Isopropanol and hexane were the major components, compared with toluene in Scandinavian studies. Performance on behavioural tests was analysed using multiple linear regression with solvent concentration as an independent variable. Other relevant demographic variables were also considered for inclusion. No significant $(p>0.05)$ relation between solvent concentration and impairment on any of the 10 behavioural variables was observed after controlling for confounding variables. Exposed/non-exposed comparisons showed a significantly poorer digit span among those exposed, but this has not been generally reported in the Scandinavian studies. The medical examination showed no abnormalities of clinical significance. The inability to replicate the findings of the Scandinavian studies could have been due to the shortness of the duration of workers' exposure, the type of solvents in the mixtures, use of different behavioural tests, or to selection factors.

The central nervous system is the primary target organ for inhaled organic solvent vapours and an impairment of central nervous system function and neuraesthenic symptoms are commonly reported

*Present address: Occupational and Environmental Health Unit, University of California, Davis, California 95616.

Received 12 November 1984

Accepted 7 January 1985 after short term, high level exposure. At low levels of exposure, evidence of frank neurotoxicity may be preceded by subtle, subclinical changes in behaviour or psychological function. ${ }^{12}$

Since the 1970s a substantial effort has been devoted to evaluating subclinical behavioural impairment among occupational groups exposed to solvents. ${ }^{3}$ Sensory perception, motor function, and higher cognitive abilities have been studied using 
performance tests adapted from clinical neurology, experimental psychology, intelligence testing, and ergonomics. Laboratory and field studies with short term exposure to relatively pure styrene,${ }^{45}$ toluene, ${ }^{6}$ and other solvents ${ }^{5}$ have shown a slowing of reaction time at concentrations close to threshold limit values (TLVs). Cross sectional epidemiological studies of long term spray painters exposed to mixtures of organic solvents have shown impairments in reaction time, spatial reasoning, visual memory, and psychomotor skills. ${ }^{78}$ These studies included exposure levels of less than one third of the TLV for mixtures and raise the possibility that synergism or long term exposure may have adverse effects on a wide range of higher cerebral functions.

An important limitation of previous epidemiological studies has been the failure to show that the severity of impairment increases with dose. ${ }^{7-12}$ Dose-response is an important criterion for establishing causality ${ }^{13}$ and for providing a quantitative basis for risk assessment and standard setting. The objective of the present study was to replicate previous cross sectional epidemiological studies and to examine dose-response effects with quantitative exposure data.

\section{Materials and methods}

\section{SELECTION OF STUDY SITES AND SUBJECTS}

Subjects were chosen from large midwestern United States companies engaged in manufacturing automotive parts or furniture and printing companies belonging to a regional trade association. Four employers (referred to as plants $1,2,3$, and 4) agreed to participate (table 1). Investigators were unrestricted in the selection of subjects at plants 2,3 , and 4 , but were restricted to self selected volunteers at plant 1 .

A cross sectional sample of subjects was selected from among hourly workers in a multistep process. Firstly, an industrial hygiene walk-through was conducted at each plant to determine which current job classifications were exposed or non-exposed to solvents (table 1). Secondly, each worker in the study population was assigned a status of "exposed" or "non-exposed," based on the walk-through survey and job classification listed on employee rosters. Thirdly, all, or a sample of exposed, were selected from employee rosters at plants 2,3 , and 4 and from sign-up sheets of volunteers at plant 1 . At plants 1 , 2 , and 3, non-exposed were chosen from employee rosters (or sign-up sheets at plant 1 ) by matching an exposed subject's plant, sex, age ( \pm 5 years) and educational level. Subjects at plant 4 were matched only on sex because of the limited number of nonexposed subjects. Subjects were then notified that they had been selected and that they would be paid to take part. They responded by informing their supervisors or the investigators if they wished to do so. Subjects who refused to take part or were otherwise unavailable for testing were replaced with other matched subjects when possible.

Of 640 workers in the sample, 269 responded and 240 , including 28 replacements, signed consent forms (table 2). A total of 124 were classified as exposed and 116 as non-exposed. The low response rate at plant 1 probably reflected management's requirement that subjects should volunteer rather than be chosen by the investigators. Response rates were higher at other plants where investigators had a direct role in selecting subjects and recruitment The response rates of the exposed did not diffeco significantly from those of the non-exposed at any plant or overall $\left(\chi^{2}, \mathrm{p}<0.05\right)$. The respondents were on average two years older than nonrespondents and at plants $1-3$, proportionately more women were respondents $(37 \%)$ than nonrespondents $(23 \%)$. These comparisons do not show any significant differences between respondents and non-respondents.

\section{CHARACTERISTICS OF SUBJECTS}

Table 3 presents the demographic characteristics of the study group $(n=240)$. The subjects were young

Table 1 Description of study sites

\begin{tabular}{|c|c|c|c|c|c|}
\hline \multirow[t]{2}{*}{ Plant } & \multirow[t]{2}{*}{ Product } & \multirow[t]{2}{*}{ Processes using solvents } & \multicolumn{2}{|l|}{ Job classifications } & \multirow{2}{*}{$\begin{array}{l}\text { Date(s) } \\
\text { production } \\
\text { started }\end{array}$} \\
\hline & & & Exposed* & Control & \\
\hline 1 & Office furniture & Spraying paint or glue & $\begin{array}{l}\text { Sprayer (paint, glue), top } \\
\text { trimmer, paint technician }\end{array}$ & $\begin{array}{l}\text { Assembler, material handler, } \\
\text { cutter, sewer }\end{array}$ & 1963 \\
\hline 2 & Office furniture & Spraying lacquer or glue & $\begin{array}{l}\text { Sprayer (glue, lacquer), rubber } \\
\text { wiper }\end{array}$ & $\begin{array}{l}\text { Assembler, cutter, sewer, } \\
\text { material handler }\end{array}$ & $1970 \mathrm{~s}$ \\
\hline 3 & Automotive parts & Spraying paint or glue & $\begin{array}{l}\text { Sprayer (paint, glue), spindle } \\
\text { washer, booth cleaner, paint } \\
\text { mixer }\end{array}$ & $\begin{array}{l}\text { Assembler, material handler, } \\
\text { machine operator }\end{array}$ & 1973 \\
\hline 4 & Printed matter & Offset printing & Pressmen, feeder operator & $\begin{array}{l}\text { Machine operator, material } \\
\text { handler, plate preparer }\end{array}$ & 1963 \\
\hline
\end{tabular}

${ }^{*}$ Exposure category based on industrial hygiene walk-through survey. 
Table 2 Enumeration of the study population, sample, respondents, non-respondents, and replacements by plant and exposure status at walk-through. (Number of exposed in parentheses)

\begin{tabular}{lccccc}
\hline Group & Plants 1-4 & Plant 1 & Plant 2 & Plant 3 & Plant 4 \\
\hline Study population & $1571(276)$ & $434(120)$ & $714(28)$ & $345(85)$ & $78(43)$ \\
Sample*: & $640(227)$ & $434(120)$ & $56(28)$ & $72(36)$ & $78(43)$ \\
Respondents & $296(114)$ & $121 \dagger(36)$ & $50(27)$ & $52(25)$ & $46(26)$ \\
Non-respondents & $371(113)$ & $313(84)$ & $6(1)$ & $20(11)$ & $32(17)$ \\
Replacements & $28(15)$ & $8(4)$ & $1(0)$ & $19(11)$ & $0(0)$ \\
Signed consent forms and tested & $240(124)$ & $72(35)$ & $51(27)$ & $71(36)$ & $46(26)$ \\
Response rate (\%)8: & 42 & 28 & 89 & 72 & 59 \\
Exposed (\%) & 50 & 30 & 96 & 69 & 60 \\
Non-exposed $(\%)$ & 38 & 27 & 82 & 75 & 57 \\
\hline
\end{tabular}

*Sample at plant 1 was self selected volunteers whose names appeared on sign-up sheets. Samples at plants $2-4$ were selected from company employee rosters.

tOf the 121 names on the sign-up sheets, 72 were selected by the investigators and 64 signed consent forms.

$\ddagger$ Replacement subjects were drawn from the plant study population.

$\S$ Response rate $=($ respondents $/$ sample $) \times 100$.

|Differences between response rates of exposed and non-exposed were not significant $\left(p>0.05, \chi^{2}\right)$.

Table 3 Characteristics of the study group

\begin{tabular}{|c|c|c|c|c|c|}
\hline Item & Plants $1-4$ & Plant 1 & Plant 2 & Plant 3 & Plant 4 \\
\hline $\begin{array}{l}\text { No* } \\
\text { Mean age } \pm \text { SD } \\
\text { Mean years education } \pm \text { SD } \\
\text { Mean years on current job } \pm \text { SD } \\
\text { Mean alcoholic drinks/day } \pm \text { SD } \\
\text { Men }(\%) \\
\text { Caucasian }(\%)\end{array}$ & $\begin{array}{l}240 \\
35 \pm 11 \\
11 \pm 2 \\
6 \pm 6 \\
1 \pm 2 \\
66 \\
90\end{array}$ & $\begin{array}{l}72 \\
36 \pm 10 \\
12 \pm 2 \\
7 \pm 6 \\
1 \pm 2 \\
96 \\
96\end{array}$ & $\begin{array}{l}51 \\
30 \pm 12 \\
11 \pm 2 \\
3 \pm 5 \\
1 \pm 1 \\
61 \\
96\end{array}$ & $\begin{aligned} 71 & \\
36 & \pm 10 \\
11 & \pm 2 \\
4 & \pm 3 \\
1 & \pm 2 \\
18 & \\
79 & \end{aligned}$ & $\begin{aligned} 46 & \\
39 & \pm 9 \\
12 & \pm 1 \\
12 & \pm 8 \\
2 & \pm 2 \\
100 & \\
93 & \end{aligned}$ \\
\hline $\begin{array}{l}\text { Cigarette smoking: } \\
\text { Never smokers }(\%) \\
\text { Current smokers }(\%) \\
\text { Ex-smokers }(\%) \\
\text { >1 Alcoholic drink/day }(\%) \\
\text { Former job as a painter or }\end{array}$ & $\begin{array}{l}32 \\
50 \\
18 \\
31\end{array}$ & $\begin{array}{l}29 \\
49 \\
23 \\
43\end{array}$ & $\begin{array}{l}53 \\
31 \\
16 \\
20\end{array}$ & $\begin{array}{r}29 \\
63 \\
8 \\
25\end{array}$ & $\begin{array}{l}22 \\
56 \\
22 \\
41\end{array}$ \\
\hline $\begin{array}{l}\text { printer }(\%) \\
\text { Hobby chemical users }(\%) \dagger \\
\text { Regular medication takers }(\%) \ddagger 1\end{array}$ & $\begin{array}{r}16 \\
7 \\
\ddagger 18\end{array}$ & $\begin{array}{r}15 \\
6 \\
15\end{array}$ & $\begin{array}{r}4 \\
8 \\
18\end{array}$ & $\begin{array}{r}13 \\
0 \\
23\end{array}$ & $\begin{array}{l}35 \\
17 \\
15\end{array}$ \\
\hline
\end{tabular}

* Missing data excluded from calculations. No more than five cases missing for any item.

†Hobby chemicals included solvents, lead, or pesticides.

¥Of 53 reports of medicine taken in 24 hours before testing, $25 \%$ were aspirin or other analgesics, $13 \%$ were antihypertensive drugs, and the remainder were uniformly spread among 11 different categories.

(mean 35$)$, mostly male $(66 \%)$ and white $(90 \%)$, high school educated (mean 11 th grade), and had not been employed on their current job and at the plant for long (mean 6, 7 years, respectively). Mean daily alcohol intake was low; $31 \%$ reported consuming more than one alcoholic beverage a day, usually as beer. Sixteen per cent reported a former job as a painter or printer. Plant 3 was mostly female whereas plants 1 and 4 were more than $96 \%$ male.

\section{TEST PROCEDURES}

Each subject completed six behavioural tests, a questionnaire covering work and medical history, and a medical evaluation. The medical evaluation included a clinical neurological examination, ${ }^{14}$ a blood chemical profile, and analyses of blood and urine for ethanol and drugs. The results of the clinical neurological examination will be reported elsewhere. The subjects were tested at the worksite, usually in batches of four for up to 16 workers a day.
Testing was completed at each plant in four or five consecutive days during 1980 and 1981. The matched pairs of exposed and non-exposed were generally tested at the same time of day to minimise the behavioural effects of circadian rhythms. The exposed subjects were tested before their shift, wherever possible, to minimise acute effects of solvent exposure.

The six tests comprising the battery are described below. Each test took about 15 minutes to complete. The tests were administered by trained and experienced personnel who were blind to the exposure status of the subjects.

Fitts law task measured psychomotor speed. ${ }^{15} 16$ Subjects tapped between two copper plates with a stylus coupled to an electronic timer. After 50 discrete tapping motions the task was made more or less difficult by varying the distance between the plates and the size of the target zone on each plate according to pre-established dimensions. The per- 
formance variable was based on the average speed for four blocks of 50 tapping motions and the corresponding plate dimensions.

Stroop test measured the ability to ignore distracting visual and verbal stimuli. ${ }^{17} 18$ Subjects were asked to name the colour of the ink in which letters were written. The letters formed either a repeating pattern of Os or spelt a word that was the name of a colour-for example blue. The colour in which the word was written always differed from the colour that the word spelt-for example "blue" in red letters. Slides of colour words and coloured Os were cued by a projector controlled by a microcomputer. The subjects were electronically timed in 70 trials on how fast they could name colours with and without interference from colour words. The total time to name colour-words (conflict stimuli), "colournaming time," was the first performance variable. The second variable, "interference time," was the time to name colours for distracting colour words minus the time to name colour Os for the same colour of ink.

Mental rotation measured spatial reasoning or visual intelligence. ${ }^{19}$ Visual stimuli, presented by a microcomputer, consisted of slides depicting normal and backwards letters, such as $R$ and $Y$, which were rotated $0^{\circ}, 60^{\circ}, 120^{\circ}$, and $180^{\circ}$ in the plane of the slide. Subjects were instructed to mentally "flip up" the image and call out "normal" or "backwards", depending on the orientation of the letter. The verbal response time was electronically recorded for $\mathbf{8 0}$ slides. The performance variable was based on the speed of the verbal response.

Memory scanning measured the rate of short term memory scanning. ${ }^{20}$ Subjects memorised a short list of one digit numbers presented on a flash card. Numbers between 0 and 9 were :hen displayed singly on a microcomputer screen. After each number was displayed, the subjects indicated whether the number was included in the memorised list by pushing a "yes" or "no" button. The time to respond was electronically recorded. The performance variables were based on response time for "yes" and "no" responses as a function of the list length of the memorised list. List lengths of two and five were used for a total of 200 trials per subject.

Memory span measured short term recall for letters. ${ }^{21}$ A list of letters was displayed one at a time on a microcomputer screen at the rate of one a second. The subject wrote (from memory) the letters in order of presentation on a prepared form.

This was repeated using 43 lists of various lengths. The performance variables were based on the length of lists that were recalled without error in $50 \%$ of trials. Responses with omissions or comissions were scored as errors, but the memory span for lists in which letters were out of order (item only) were considered separately from those in which the letters were in the correct order (item and order).

Continuous recognition memory measured the ability to remember digits after a lapse of up to 40 seconds. ${ }^{22}$ The subjects were presented with a list of three digit numbers, displayed singly on a microcomputer screen at the rate of one every five seconds. About two thirds of the numbers were repeated. After each number was displayed, the subjects indicated whether the number had been previously displayed by pushing an "old" or "new" button. The response variable was based on the accuracy of responses during 15 minutes of trials.

\section{RELIABILITY AND STATISTICAL POWER OF BEHAVIOURAL TESTS}

Test-retest reliabilities for the Stroop test, memory scanning, and memory span are greater than $0.85^{21}{ }^{23}$ (AM Rose, unpublished data). Based on prior research and the number of tested subjects, the statistical power of the Fitts test, Stroop colour naming test, and memory span was sufficient to detect $5 \%$ differences in test scores between exposed and non-exposed with a $90 \%$ certainty $(\alpha=0.05)$. The least significant differences $(\alpha=0.05)$ in test scores detectable with $90 \%$ power was $15-20 \%$ for memory scanning, continuous recognition memory, and Stroop interference.

DESCRIPTION OF WORK PROCESS AND EXPOSURE The materials and work processes were similar at plants 1, 2, and 3 and have been described by Whitehead et al. ${ }^{24}$ Paint vehicles contained alkyd resins and mixtures of aromatic solvents, chlorinated and oxygenated aliphatic solvents, alcohols, and acetates. Fillers contained various pigments but lead pigments were used infrequently. The paints also contained various additives including biocides, stabilisers, and antiskinning agents. Glues contained toluene, hexane, and chlorinated hydrocarbon solvents.

Metal or plastic parts were placed on a conveyer line or were positioned at a work station. Parts were sprayed with hand held spray guns that nebulised the paint, lacquer, or glue with or without a pressurised air stream. Spray booths were ventilated and equipped with either a water curtain or dry filters. Painted or glued parts were taken to areas where these and other components were upholstered, assembled, packed, and shipped. Exposure to solvent also occurred during paint mixing, cold cleaning, wiping, touch up, and disposal of waste paint.

At plant 4, a one to four man team operated each of seven offset printing presses that consumed various inks and solvents. Printing plates were com- 
posed in separate areas using a photoetching or lithographic process. A bindery and material handling department were located in the basement.

The original ventilation systems were still in use at each plant at the time of the study. The ventilation system at plant 4 recirculated contaminated pressroom air which led to heavy contamination of all production areas. No workers engaged in solvent operations wore solvent collecting respirators.

The breathing zone of 112 "exposed" and 47 "non-exposed" was sampled with a personal breathing zone sampler for roughly a full workshift during the week of behavioural testing. Subjects for whom air samples were not taken were assumed to have the same exposure as a sampled subject within the same plant, job title, and department. Twenty individual solvents were identified using gas chromatography mass spectroscopy and infrared spectrophotometry, and routinely quantitated using gas chromatography.

Solvent concentrations, expressed as full shift time weighted averages (TWA), are presented in table 4 . The mean total solvent concentrations at the furniture and automotive parts plants (plants 1-3) were low but at the printing plant (plant 4) the mean total solvent concentration, which was dominated by isopropanol, naphtha, hexane, and xylene, exceeded $300 \mathrm{ppm}$. The mean total concentration among the non-exposed at plant 4 was about eight times greater than that of exposed at the other plants (table 5). This finding indicates that the exposed/non-exposed classification scheme introduces a considerable degree of misclassification with respect to demonstrable solvent exposures. Further analyses rely primarily on the quantitative solvent measurements. To maintain consistency with Scandinavian studies,
Table 5 Mean solvent concentration (ppm) by exposure status at walk-through. * (Number of subjects in parentheses)

\begin{tabular}{lcc}
\hline Plant & Exposed & Non-exposed \\
\hline 1 & $17(35)$ & $1(37)$ \\
2 & $24(27)$ & $9(24)$ \\
3 & $20(36)$ & $5(35)$ \\
4 & $385(26)$ & $193(20)$ \\
$1-4$ & $96(124)$ & $37(116)$ \\
\hline
\end{tabular}

*Includes assumed values of unsampled subjects.

comparisons of "exposed" and "non-exposed" will also be presented.

In addition to total solvent concentration, other exposure variables were constructed from measurements of air borne solvents, duration of employment, and a scale that weighted the toxicity of various solvent components relative to toluene and xylene. ${ }^{25}$ Each of these exposure variables was highly correlated with total solvent concentration and with each other. For analytical purposes, only the total solvent concentration will be presented, although the other exposure variables yielded similar results.

\section{STATISTICAL METHODS}

Based on prior knowledge,' age, sex, education, and alcohol intake were considered to be the most important potential confounders of performance. Potential confounding was examined by correlation analysis (table 6). Because performance on most tests in the battery declines with age ${ }^{26}$ and possibly with alcohol intake, an impairment due to age or alcohol intake may be misattributed to solvent exposure. Sex affects performance of mental rotation and Stroop colour naming time by $5-10 \%$; men

Table 4 Per cent cumulative TLV $V^{34}$ and mean concentration (ppm) of solvents in breathing zone air by plant*

\begin{tabular}{|c|c|c|c|c|c|c|c|c|c|c|}
\hline \multirow[t]{2}{*}{ Solvent } & \multicolumn{2}{|c|}{ Plants $1-4$} & \multicolumn{2}{|l|}{ Plant 1} & \multicolumn{2}{|c|}{ Plant 2} & \multicolumn{2}{|l|}{ Plant 3} & \multicolumn{2}{|c|}{ Plant 4} \\
\hline & Mean & $S D$ & Mean & $S D$ & Mean & $S D$ & Mean & $S D$ & Mean & $S D$ \\
\hline $\begin{array}{l}\text { \% TLV } \\
\text { Total solvent } \\
\text { Isopropanol } \\
\text { Methylene chloride } \\
\text { Trichloroethylene } \\
\text { Acetone } \\
\text { 2-Butanone (MEK) } \\
\text { Naphtha§ } \\
\text { Toluene } \\
\text { Xylene } \\
\text { Ethylbenzene } \\
\text { Hexane } \\
\text { Residual }\end{array}$ & $\begin{array}{r}40 \\
68 \\
31 \\
2 \\
1 \\
4 \\
0 \\
10 \\
3 \\
4 \\
1 \\
8 \\
-\end{array}$ & $\begin{array}{r}71 \\
126 \\
70 \\
10 \\
2 \\
8 \\
3 \\
22 \\
6 \\
9 \\
2 \\
17 \\
-\end{array}$ & $\begin{array}{l}6 \\
9 \\
0 \| \\
0 \\
2 \\
1 \\
0 \\
0 \\
2 \\
1 \\
0 \\
1 \\
1\end{array}$ & $\begin{array}{r}9 \\
12 \\
0 \\
4 \\
3 \\
2 \\
0 \\
5 \\
3 \\
3 \\
1 \\
1 \\
2\end{array}$ & $\begin{array}{r}13 \\
17 \\
0 \\
2 \\
1 \\
1 \\
0 \\
1 \\
5 \\
1 \\
0 \\
1 \\
3\end{array}$ & $\begin{array}{r}15 \\
18 \\
2 \\
6 \\
1 \\
3 \\
0 \\
3 \\
9 \\
2 \\
1 \\
2 \\
5\end{array}$ & $\begin{array}{r}9 \\
12 \\
1 \\
4 \\
0 \\
2 \\
0 \\
0 \\
2 \\
0 \\
0 \\
1 \\
2\end{array}$ & $\begin{array}{r}19 \\
26 \\
6 \\
16 \\
0 \\
7 \\
1 \\
0 \\
4 \\
1 \\
0 \\
2 \\
4\end{array}$ & $\begin{array}{r}170 \\
302 \\
161 \\
1 \\
0 \\
15 \\
4 \\
50 \\
6 \\
20 \\
5 \\
39 \\
-\quad\end{array}$ & $\begin{array}{r}65 \\
117 \\
70 \\
2 \\
0 \\
9 \\
7 \\
20 \\
5 \\
11 \\
3 \\
18 \\
-\end{array}$ \\
\hline
\end{tabular}

*Includes assumed values of unsampled subjects.

† Methyl isobutyl ketone (MiBK), propyl benzene, cumene, heptane, butyl acetate, isobutyl acetate, isopropyl acetate, isobutyl butyrate, and butyl cellosolve were present at mean concentrations of less than $1 \mathrm{ppm}$.

$\ddagger \% \mathrm{TLV}=100 \times \Sigma C_{n} / T_{n}$, where $C$ is the concentration of the nth solvent in a mixture and $T$ is the threshold limit value for that solvent. \$Assumes an average molecular weight of 100 .

$\| 0=<0.5 \mathrm{ppm} ;-=$ not determined at plant 4 . 
Table 6 Correlation between demographic variables and solvent exposure (ppm) $\dagger$

\begin{tabular}{|c|c|c|c|c|c|}
\hline Variable & Age & Sex§ & Education & $\begin{array}{l}\text { Alcohol } \\
\text { intake\| }\end{array}$ & Solvent $\ddagger$ \\
\hline $\begin{array}{l}\text { Age } \\
\text { Sex } \\
\text { Education } \\
\text { Alcohol }\end{array}$ & - & $\begin{array}{l}0.04 \\
-\end{array}$ & $\begin{array}{l}-0 \cdot 29^{* *} \\
-0 \cdot 19^{* *} \\
-\end{array}$ & $\begin{array}{l}-0.06 \\
-0.24^{* *} \\
0.07 \\
-\end{array}$ & $\begin{array}{l}0.09 \\
-0.31^{* *} \\
0.02 \\
0.16^{*}\end{array}$ \\
\hline
\end{tabular}

${ }^{*} \mathrm{p}<0.05{ }^{* *} \mathrm{p}<0.01$.

tData combined for four plants; four cases missing $(n=236)$.

¥Solvent $=$ total solvent concentration (ppm).

$\S$ Sex indicator variable: 0 , men; 1 , women.

\|Alcohol intake $=$ mean daily drinks.

perform better on tasks needing mental rotation and women perform better on spontaneous verbal tasks. ${ }^{17} 27$ The correlation analysis (table 6) indicates that sex may introduce a moderate positive bias on the Stroop test but a moderate negative (masking) bias on the mental rotation test. Education was not considered to be an important confounding factor.

Dose-response was investigated with univariate plots of performance versus total solvent concentration, simple linear regression, and stepwise, forward multiple regression models ${ }^{28}$ in which total solvent concentration (ppm), plant, age, sex, years of education, mean daily alcohol intake, previous job (as a painter or printer), and hobby (entailing potential exposure to lead, solvents, or pesticides) were candidate variables. The significance level for including a term was $p<0 \cdot 1$. In multivariate regressions error residuals were visually inspected and satisfied conditions for normality and independence.

The mean performance between those classified as exposed and non-exposed on the walk-through survey was compared using 2 tailed $t$ tests for unpaired data.

Fourteen subjects for whom English was a second language and one who admitted taking amphetamine immediately before testing were excluded in the analyses of psychological tests. The medical evaluation did not show a clinically significant physical impairment that warranted any subject's exclusion from the psychological tests. Laboratory studies did not show detectable blood ethanol for any subject.

\section{Results}

Performance on selected variables from each behavioural test is plotted against total solvent concentration by plant in figs $1-6$. The slope and intercept for a simple linear regression between performance and total solvent concentration is presented in table 7 for each performance variable. The results of stepwise multiple linear regression are summarised in table 8; mean performance by plant is summarised in table 9.

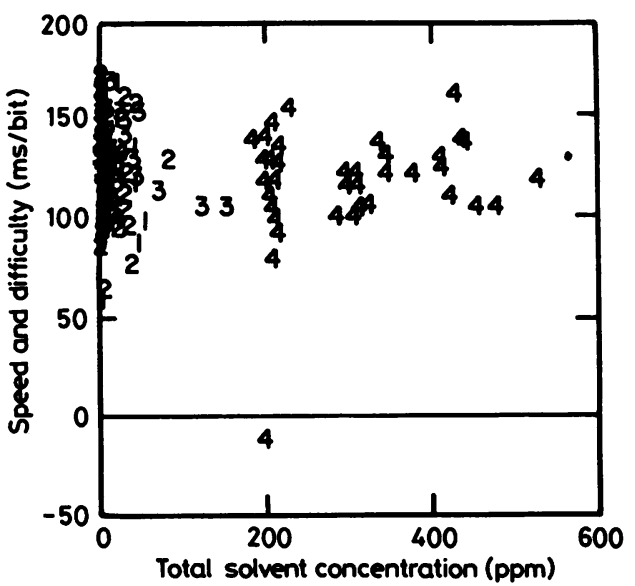

Fig 1 Fitts law task (speed and difficulty) versus total solvent concentration by plant.

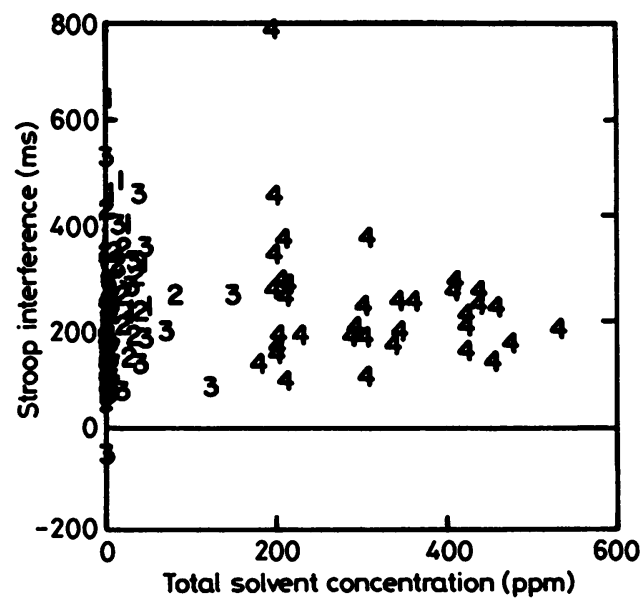

Fig 2 Stroop interference time versus total solvent concentration by plant.

FITTS LAW TASK

The plot of Fitts law "speed and difficulty" shows highly variable responses but no association be- 


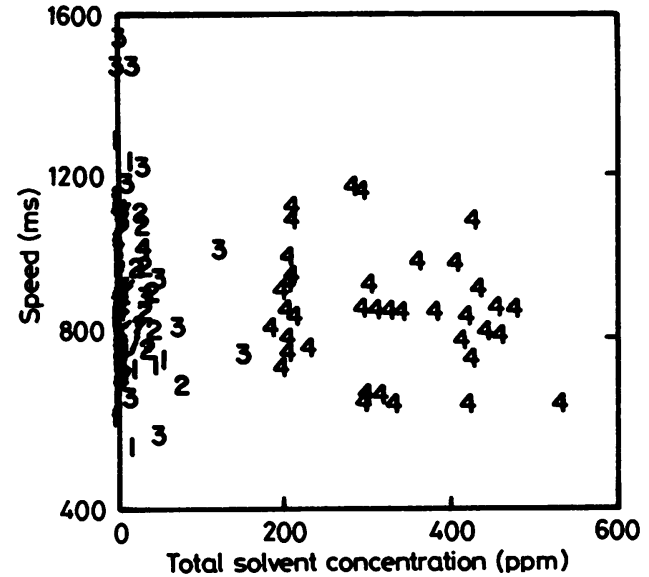

Fig 3 Mental rotation time versus total solvent concentration by plant.

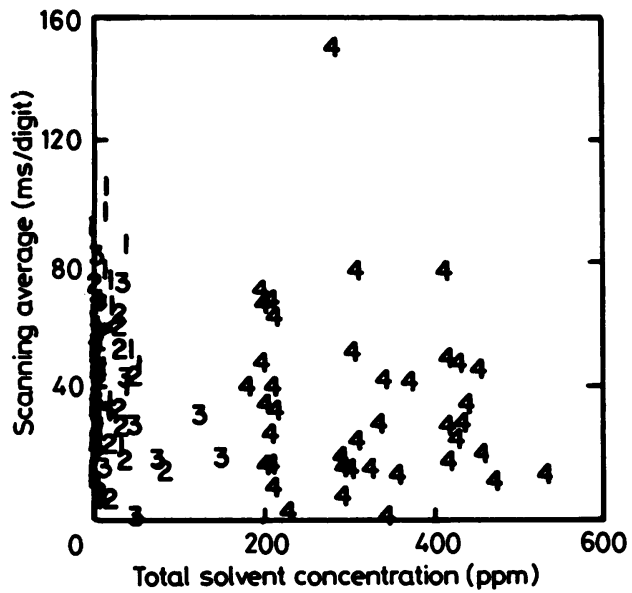

Fig 4 Sternberg memory scanning rate versus total solvent concentration by plant.

ween performance and solvent level at individual plants or overall (fig 1). In univariate or multivariate regressions (tables 7-8) solvent concentration was not significantly related to performance $(p>0.05)$. Performance among subjects at plant 3 was slightly poorer $(p=0.03)$ on average than that of subjects at other plants (table 8).

\section{STROOP COLOUR WORD TEST}

The plot of Stroop interference time does not depict a trend with solvent concentration (fig 2); significant linear dose-response relation were not found in univariate or multiple linear regression. Age and plant 3 were significant $(p<0.005)$ predictors of performance (table 8).

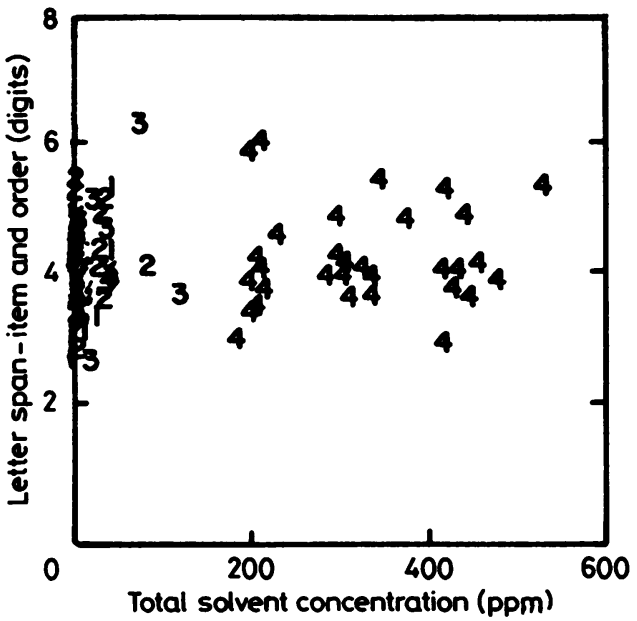

Fig 5 Memory span (item and order) versus total solvent concentration by plant.

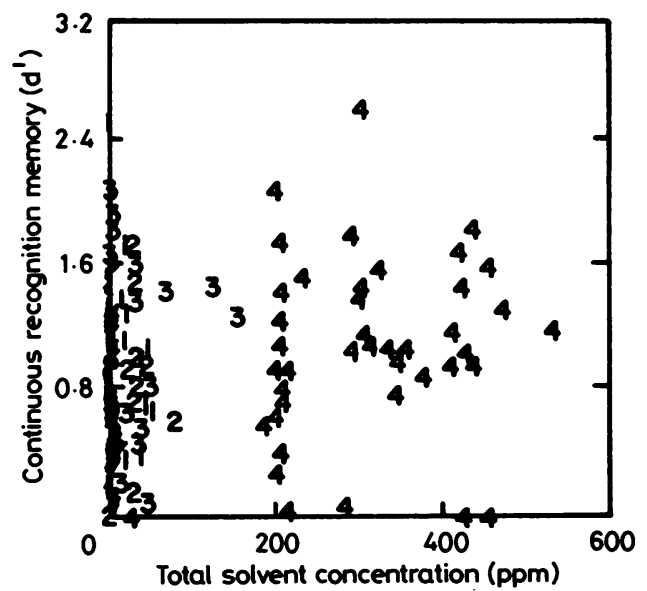

Fig 6 Continuous recognition memory $\left(d^{\prime}\right)$ versus total solvent concentration by plant.

Stroop colour naming time was not significantly associated with solvent level at any plant or overall (tables 7-8). In agreement with previous research colour naming time was significantly slower with increasing age $(p<0.001)$ and significantly faster among women $(\mathrm{p}<0.001)$ (table 8$)$. In multivariate analysis subjects at plant 2 were slightly slower than other subjects $(p=0 \cdot 02)$.

\section{MENTAL ROTATION}

The plot of mental rotation speed shows a highly variable response but no obvious correlation with solvent concentration overall or any plant (fig 3). The simple linear trend among plant 4 subjects was 
Table 7 Simple linear regression of psychological performance and total solvent concentration (ppm) by plant

\begin{tabular}{|c|c|c|c|c|c|c|c|c|c|c|}
\hline \multirow[t]{2}{*}{$\begin{array}{l}\text { Performance test } \dagger \\
\text { (psychological function) }\end{array}$} & \multicolumn{2}{|c|}{$\begin{array}{l}\text { Plants 1-4 } \\
(n \dagger=201-217)\end{array}$} & \multicolumn{2}{|c|}{$\begin{array}{l}\text { Plant } 1 \\
(n=62-70)\end{array}$} & \multicolumn{2}{|c|}{$\begin{array}{l}\text { Plant } 2 \\
(n=41-46)\end{array}$} & \multicolumn{2}{|c|}{$\begin{array}{l}\text { Plant } 3 \\
(n=54-62)\end{array}$} & \multicolumn{2}{|c|}{$\begin{array}{l}\text { Plant } 4 \\
(n=40-45)\end{array}$} \\
\hline & Intercept & Slope & Intercept & Slope & Intercept & Slope & Intercept & Slope & Intercept & Slope \\
\hline $\begin{array}{l}\text { Fitts law task } \$ \text { (psychomotor) } \\
\text { speed \& difficulty (msec/bitt) }\end{array}$ & 124 & -0.011 & 124 & $-0 \cdot 16$ & 119 & 0.072 & 130 & -0.098 & 109 & 0.034 \\
\hline $\begin{array}{l}\text { Stroop test (freedom from distraction) } \\
\text { Interference (msec) } \\
\text { Colour naming (msec) }\end{array}$ & $\begin{array}{r}230 \\
1107\end{array}$ & $\begin{array}{l}0 \cdot 016 \\
0.08\end{array}$ & $\begin{array}{r}246 \\
1108\end{array}$ & $\begin{array}{l}0.70 \\
1.42\end{array}$ & $\begin{array}{r}232 \\
1129\end{array}$ & $\begin{array}{r}0 \cdot 04 \\
-0 \cdot 16\end{array}$ & $\begin{array}{r}192 \\
1069\end{array}$ & $\begin{array}{l}0.44 \\
0.25\end{array}$ & $\begin{array}{r}257 \\
1193\end{array}$ & $\begin{array}{r}0.07 \\
-0.18\end{array}$ \\
\hline $\begin{array}{l}\text { Mental rotation (visual intelligence) } \\
\text { Speed (msec) }\end{array}$ & 906 & -0.10 & 879 & 0.68 & 901 & $-0 \cdot 45$ & 943 & -0.46 & 1017 & $-0.41^{*}$ \\
\hline $\begin{array}{l}\text { Memory scanning (memory) } \\
\text { No-scanning (msec/item) } \\
\text { Yes-scanning (msec/item) }\end{array}$ & $\begin{array}{l}44 \cdot 7 \\
38 \cdot 4\end{array}$ & $\begin{array}{r}0.01 \\
-0.02\end{array}$ & $\begin{array}{l}50 \cdot 8 \\
46 \cdot 1\end{array}$ & $\begin{array}{l}0 \cdot 37 \\
0 \cdot 09\end{array}$ & $\begin{array}{l}31 \cdot 0 \\
32 \cdot 0\end{array}$ & $\begin{array}{r}0.17 \\
-0.11\end{array}$ & $\begin{array}{l}41 \cdot 8 \\
34 \cdot 6\end{array}$ & $\begin{array}{l}-0.05 \\
-0.11\end{array}$ & $\begin{array}{l}54 \cdot 1 \\
38 \cdot 3\end{array}$ & $\begin{array}{l}-0.03 \\
-0.02\end{array}$ \\
\hline $\begin{array}{l}\text { Memory span (short term memory) } \\
\text { Item \& order (digits) } \\
\text { Item only (digits) }\end{array}$ & $\begin{array}{l}4 \cdot 2 \\
4 \cdot 5\end{array}$ & $\begin{array}{l}0.001 \\
0.001\end{array}$ & $\begin{array}{l}4 \cdot 4 \\
4 \cdot 7\end{array}$ & $\begin{array}{l}-0.005 \\
-0.004\end{array}$ & $\begin{array}{l}4 \cdot 2 \\
4 \cdot 6\end{array}$ & $\begin{array}{r}0.002 \\
-0.002\end{array}$ & $\begin{array}{l}4 \cdot 0 \\
4 \cdot 4\end{array}$ & $\begin{array}{l}0.006 \\
0.004\end{array}$ & $\begin{array}{l}3 \cdot 8 \\
4 \cdot 5\end{array}$ & $\begin{array}{l}0 \cdot 001 \\
0 \cdot 001\end{array}$ \\
\hline $\begin{array}{l}\text { Continuous recognition memory } \\
\text { (intermediate memory) } d^{\prime}\end{array}$ & 0.88 & $0.001^{*}$ & 0.90 & 0.001 & 0.91 & 0.001 & $0 \cdot 84$ & 0.003 & 0.72 & 0.001 \\
\hline
\end{tabular}

*Slope significantly different than 0 at $\mathrm{p}<0.05$.

tLower values reflect better performance on all tests except continuous recognition and memory span.

$¥$ Variable $\boldsymbol{n}$ due to missing values on some tests.

All $r^{2} s<0.08$ except mental rotation at plant $4\left(r^{2}=0.12\right)$.

Table 8 Stepwise forward, multiple linear regression of six psychometric tests: improvement (+) or impairment (-) of psychological performance associated with demographic variables and exposure to mixtures of organic solvents

\begin{tabular}{|c|c|c|c|c|c|c|c|c|c|}
\hline $\begin{array}{l}\text { Test } \\
\text { (function) }\end{array}$ & $\begin{array}{l}\text { Fitts law task } \\
\text { (psychomotor) }\end{array}$ & $\begin{array}{l}\text { Stroop colo } \\
\text { test } \\
\text { (freedom fr } \\
\text { distraction) }\end{array}$ & $\begin{array}{l}\text { lour-word } \\
\text { from } \\
\text { a) }\end{array}$ & $\begin{array}{l}\text { Mental rotation test } \\
\text { (visual intelligence) }\end{array}$ & $\begin{array}{l}\text { Sternber } \\
\text { scanning } \\
\text { (memor }\end{array}$ & $\begin{array}{l}\text { nemory } \\
\text { peed) }\end{array}$ & $\begin{array}{l}\text { Memory } \\
\text { (memory }\end{array}$ & $\begin{array}{l}\text { span test } \\
\text { capacity) }\end{array}$ & $\begin{array}{l}\text { Continuous } \\
\text { recognition memory } \\
\text { (intermediate memory, }\end{array}$ \\
\hline Variable† & $\begin{array}{l}\text { Speed \& difficulty } \\
\text { (msec/bit) }\end{array}$ & $\begin{array}{l}\text { Interference } \\
\text { (msec) }\end{array}$ & $\begin{array}{l}\text { e Colour } \\
\text { naming } \\
\text { (msec) }\end{array}$ & Speed (msec) & $\begin{array}{l}\text { No } \\
\text { scaning }\end{array}$ & $\begin{array}{l}\text { Yes } \\
\text { scaning }\end{array}$ & $\begin{array}{l}\text { Item } \\
\& \text { order } \\
\text { (digits) }\end{array}$ & $\begin{array}{l}\text { Item } \\
\text { only } \\
\text { (digits) }\end{array}$ & $d^{\prime}$ \\
\hline $\begin{array}{l}\text { Age } \\
\text { Sex }(0=M, 1=F) \\
\text { Education } \\
\text { Plant } 2^{*} \\
\text { Plant } 3 \\
\text { Plant } 4 \\
\text { Shift }(0=\text { before } 1= \\
\quad \text { during, after) } \\
\text { Hour of test } \\
\text { Prior employment } \ddagger \\
\text { Hobby exposure } \\
\text { Total solvent (ppm) } \\
r^{2}\end{array}$ & 0.02 & 0.09 & $\begin{array}{l}- \\
+ \\
-\end{array}$ & $\begin{array}{l}- \\
0 \cdot 18\end{array}$ & $\begin{array}{l}+ \\
- \\
+ \\
0 \cdot 16\end{array}$ & $\begin{array}{l}- \\
+ \\
0 \cdot 14\end{array}$ & $\begin{array}{l}- \\
0 \cdot 12\end{array}$ & 0.11 & $\begin{array}{l}+ \\
+ \\
0.08\end{array}$ \\
\hline
\end{tabular}

* Plant dummy variables relative to plant 1 .

tAll $(+)$ and $(-)$ significant at $p<0.01$. Alcohol and regular medications did not enter any model at $p<0.01$.

$\ddagger$ Former printer or painter.

significant $(p<0.05)$; however, performance improved with increasing solvent concentration. Age was not controlled in this simple regression and may have contributed to the negative association through its association with solvent exposure $\left(r_{(a g e)}\right.$ $=-0 \cdot 46)$. No significant trend with solvent concentration was found by combining responses from all four plants (table 7). According to the multiple linear regression model, age $(p=0.001)$, sex $(p<$ $0.001)$, hobby chemical use $(p=0.06)$ were significant predictors of performance. The predicted direction of effect of increasing age, sex, and hobby chemical use was toward poorer performance, as expected.

\section{MEMORY SCANNING}

A plot of the average of "yes" and "no" memory scanning is presented in fig 4; (yes and no scanning times were highly correlated, $r=0.7$ ). No association between performance and total solvent concentration is apparent at individual plants or overall. Simple linear regression of either yes scanning time or no scanning time and total solvent concentration was non-significant by plant or overall. According to the multiple linear regression model, speed of yes or no scanning improved with increasing solvent concentration ( $p=0.09, p<0.001)$. Effects related to plant, former employment, and hobbies were also indicated by the model. Subjects who reported using 
ble 9 Mean performance on psychological tests by plant

\begin{tabular}{|c|c|c|c|c|c|c|}
\hline \multirow{2}{*}{$\begin{array}{l}\text {-formance testt } \\
\text { iychological function) }\end{array}$} & Plants $1-4$ & Plants 1-3 & Plant 1 & Plant 2 & Plant 3 & Plant 4 \\
\hline & \multicolumn{3}{|c|}{$(\mathrm{n}=201-217)(n=159-177)(n=62-70)$} & $(n=41-46)$ & $(n=54-62)$ & $(n=40-45)$ \\
\hline $\begin{array}{l}\text { its law task (psychomotor) } \\
\text { Speed \& difficulty } \pm \text { SD (msec/bit) } \\
\text { ioop test (freedom from distraction) }\end{array}$ & $123 \pm 24$ & $124 \pm 22$ & $123 \pm 23$ & $120 \pm 24$ & $129 \pm 20$ & $119 \pm 28$ \\
\hline $\begin{array}{l}\text { Interference } \pm \mathrm{SD}(\mathrm{msec})^{*} \\
\text { Colour naming } \pm \mathrm{SD}(\mathrm{msec}) \\
\text { ental rotation (visual intelligence) }\end{array}$ & $\begin{array}{r}231 \pm 112 \\
1112 \pm 185\end{array}$ & $\begin{array}{r}229 \pm 111 \\
1105 \pm 179\end{array}$ & $\begin{array}{r}252 \pm 125 \\
1121 \pm 198\end{array}$ & $\begin{aligned} 238 & \pm 80 \\
1127 & \pm 156\end{aligned}$ & $\begin{array}{r}198 \pm 107 \\
1073 \pm 170\end{array}$ & $\begin{array}{r}236 \pm 120 \\
1142 \pm 206\end{array}$ \\
\hline $\begin{array}{l}\text { Speed } \pm \text { SD (msec) } \\
\text { emory scanning (memory speed) }\end{array}$ & $899 \pm 152$ & $901 \pm 155$ & $874 \pm 137$ & $895 \pm 107$ & $938 \pm 197$ & $893 \pm 140$ \\
\hline $\begin{array}{l}\text { No-scanning } \pm \text { SD }(\text { msecitem })^{* *} \\
\text { Yes-scanning } \pm \text { SD (msec/item) } \\
\text { emory span (short-term memory) }\end{array}$ & $\begin{array}{l}44 \pm 28 \\
37 \pm 24\end{array}$ & $\begin{array}{l}44 \pm 26 \\
38 \pm 23\end{array}$ & $\begin{array}{l}54 \pm 28 \\
47 \pm 28\end{array}$ & $\begin{array}{l}33 \pm 22 \\
31 \pm 18\end{array}$ & $\begin{array}{l}41 \pm 24 \\
33 \pm 18\end{array}$ & $\begin{array}{l}45 \pm 33 \\
32 \pm 24\end{array}$ \\
\hline $\begin{array}{l}\text { Item \& order } \pm \text { SD (digits) } \\
\text { Item only } \pm \text { SD (digits) }\end{array}$ & $\begin{array}{l}4.2 \pm 0.7 \\
4.6 \pm 0.8\end{array}$ & $\begin{array}{l}4 \cdot 2 \pm 0.7 \\
4.6 \pm 0.8\end{array}$ & $\begin{array}{l}4.3 \pm 0.7 \\
4.7 \pm 0.9\end{array}$ & $\begin{array}{l}4 \cdot 2 \pm 0.5 \\
4 \cdot 5 \pm 0 \cdot 6\end{array}$ & $\begin{array}{l}4 \cdot 1 \pm 0 \cdot 7 \\
4 \cdot 4 \pm 0 \cdot 8\end{array}$ & $\begin{array}{l}4.2 \pm 0.9 \\
4.6 \pm 0.7\end{array}$ \\
\hline $\begin{array}{l}\text { ntinuous recognit } \\
j^{\prime} \pm \text { SD }\end{array}$ & $0.93 \pm 0.5$ & $0.90 \pm 0.5$ & $0.91 \pm 0.5$ & $0.91 \pm 0.5$ & $0.87 \pm 0.5$ & $1.1 \pm 0.6$ \\
\hline
\end{tabular}

Means between plants significantly different (F-test, ANOVA) $\mathrm{p}<0.05$.

'p $<0.01$.

ower values reflect better performance on all tests except continuous recognition memory and memory span.

$\checkmark$ ariable $\mathbf{n}$ due to missing values on some tests.

solvents, lead, or pesticides in a hobby were slower than subjects who did not. Subjects reporting former employment as a painter or printer were faster than other subjects.

\section{MEMORY SPAN}

The 50\% threshold memory span for letters recalled in correct order was not associated with solvent level (fig 5). In univariate or multivariate analyses, memory span-item and order and span-item only were not significantly related to solvent level. Education was associated with a longer span ( $p<0.001$ ), as expected. Subjects tested before their work shift and those tested relatively later in the day (mean hour 1035) performed slightly better $(p<0.06)$ than other subjects.

\section{CONTINUOUS RECOGNITION MEMORY}

Accuracy of recognition memory is plotted against solvent concentration in fig 6. A significant linear trend, indicating increasing accuracy with increasing solvent concentration, was found overall $(p<0.05)$ (table 7). This was also found in the multivariate analysis $(p<0.005)$ (table 8$)$. Subjects reporting previous employment as a painter or printer had slightly better performance $(p=0.06)$.

\section{EXPOSED/NON-EXPOSED COMPARISONS}

As previously noted, "exposed" and "non-exposed" categories based on the initial walk-through assessment of exposure introduce considerable misclassification of demonstrable exposures. For completeness and consistency with Scandinavian studies, performance between these groups is compared in table 10. Combining over plants, exposed and non-exposed, were similar with respect to mean age, mean educational level, mean daily alcohol intake, and sex distribution. The exposed group at plant 4 was on average six years younger than non-exposed $(38 v 44)$, but the exposed consumed a greater Table 10 Behavioural performance: percentage impairment $(-)$ or improvement $(+)$ of exposed relative to non-exposed $\dagger$

\begin{tabular}{|c|c|c|c|c|c|}
\hline $\begin{array}{l}\text { Performance test } \dagger \\
\text { (psychological function) }\end{array}$ & Plants $1-4$ & Plant 1 & Plant 2 & Plant 3 & Plant 4 \\
\hline Fitts law task (psychomotor) & $-5^{*}$ & -2 & -7 & -5 & -7 \\
\hline $\begin{array}{l}\text { Stroop test (freedom from distraction) } \\
\text { Interference (msec) } \\
\text { Colour naming (msec) }\end{array}$ & $\begin{array}{l}-11 \\
-4\end{array}$ & $\begin{array}{l}-34^{* *} \\
-10\end{array}$ & $\begin{array}{l}-16 \\
-2\end{array}$ & $\begin{array}{l}-7 \\
-5\end{array}$ & $\begin{array}{l}+14 \\
+3\end{array}$ \\
\hline $\begin{array}{l}\text { Mental rotation (visual intelligence) } \\
\text { Speed (msec) } \\
\text { Memory scanning (memory) }\end{array}$ & -2 & -3 & 0 & -7 & +5 \\
\hline $\begin{array}{l}\text { No-scanning (msec/item) } \\
\text { Yes-scanning (msec/item) }\end{array}$ & $\begin{array}{l}-10 \\
-4\end{array}$ & $\begin{array}{l}-16 \\
-2\end{array}$ & $\begin{array}{l}+9 \\
+3\end{array}$ & $\begin{array}{l}-17 \\
-4\end{array}$ & $\begin{array}{r}0 \\
+2\end{array}$ \\
\hline $\begin{array}{l}\text { Memory span (short term memory) } \\
\text { Item \& order (digits) } \\
\text { Item only (digits) }\end{array}$ & $\begin{array}{l}-5^{*} \\
-6^{* * *}\end{array}$ & $\begin{array}{l}-11^{* * *} \\
-12^{* * *}\end{array}$ & $\begin{array}{l}-5 \\
-4\end{array}$ & $\begin{array}{l}-4 \\
-5 \\
-7\end{array}$ & +2 \\
\hline $\begin{array}{l}\text { Continuous recognition memory } \\
\text { (intermediate memory) } d^{\prime}\end{array}$ & $\begin{array}{l}-6+4 \\
+2\end{array}$ & $\begin{array}{l}-12+4 \\
-7\end{array}$ & $\begin{array}{l}-4 \\
+14\end{array}$ & -10 & +29 \\
\hline
\end{tabular}

*p $<0.10 ;{ }^{* *} p<0.05 ;{ }^{* * *} p<0.01$.

$+100 \times($ mean of exposed-mean of non-exposed $) /$ mean of non-exposed. 
number of alcoholic beverages a day $(2 v 1)$. These differences tend to introduce small confounding biases in different directions.

On the Fitts task, the exposed performed less well than non-exposed by approximately $5 \%(p>0.05)$ at each plant and overall.

The Stroop interference time was $10 \%$ greater ( $p$ $>0.05$ ) among the exposed than the non-exposed overall. Performance was significantly worse for the exposed at plant 1 , but the exposed at plant 4 were $16 \%$ faster than the non-exposed $(p>0.05)$. A similar relation was found for colour naming time.

There were no significant differences in speed of mental rotation between the exposed and the nonexposed.

The exposed were slightly faster $(p>0.05)$ than the non-exposed in no-scanning overall and at plants 1 and 3 . There were small, non-significant differences in yes-scanning rate between the exposure groups.

Combining over plants, the exposed had a significantly smaller memory span (item only) than the non-exposed. This was largely accounted for by the performance of the exposed at plant 1 . Memory span (item and order) was slightly smaller ( $p>$ 0.05 ) among the exposed than the non-exposed.

No significant differences in accuracy between exposure groups was found on the continuous recognition memory test. Of note, the exposed at plant 4 were $29 \%$ more accurate than the nonexposed.

\section{Discussion}

The dose-response relations observed in this study do not confirm previous reports of behavioural impairments among workers exposed to mixtures of organic solvents below recommended limits. ${ }^{7-12}$ As in previous studies, the comparison of the exposed and the non-exposed showed some minor deficiencies among the exposed. Memory span of the exposed was significantly less than that of the nonexposed, but this has not been generally reported. Whereas exposed/non-exposed differences are not readily explained, exposure to solvents is probably not responsible since impairments were not observed in more powerful analyses of doseresponse. These findings will be discussed below taking into account differences between this and previous studies and methodological limitations.

\section{COMPARABILITY OF STUDIES}

There are important differences between the Scandinavian studies and the present study. Firstly, the average duration of employment (exposure) was seven years in the present study compared with 14 years in other studies concerning solvent mixtures. $^{7-12}$

Secondly, the main component of solvent exposure in previous studies was toluene, but isopropanol, which is probably less potent, was the dominant exposure of this study (table 4). Thus short duration of exposure and less potent components in the exposure may contribute to the lack of performance-exposure associations on behavioural tests.

Thirdly, how do the test batteries compare in scope and sensitivity? Direct comparisons are limited to memory span tests for which the version in the present study $^{23}$ has a greater sensitivity than that based on Wechsler's digit span. ${ }^{29}$ With the exception of simple reaction time, the range of abilities appears to be similar in the present and Wechsler based Scandinavian batteries. Our power calculations suggest that the tests comprising the present battery can detect small differences in performance of the same magnitude as impairments reported by previous studies $(5 \%$ to $15 \%)$. Moreover, responses correlated with age, sex, and education as predicted from previous research..$^{182627}$

\section{METHODOLOGY}

It was assumed that performance was accurately described by linear additive models in which confounding was adequately controlled. Goodness of fit was examined by comparing model predictions with means stratified by plant, sex, age, education, and other variables. For the Fitts law, Stroop colour naming, and memory span (item only) observed versus predicted agreed within $5 \%$. Whereas the goodness of fit was poorer for other parameters (generally, 13-25\%), there was agreement in the direction of response. Given the great variability of response, it is doubtful whether non-linear models would have been more efficient or have led to different conclusions.

Several potentially confounding relations concerning age, sex, alcohol, and plant were identified (table 6), but only sex in the test of mental rotation could have masked solvent related impairments or contributed to the apparent improvement in performance. Other factors, possibly unquantified, may have contributed to other associations, suggesting a beneficial effect of solvent exposure. Of particular concern are selection biases, subject motivation, skill level of jobs, nature of past exposures, or observer/subject bias.

Non-response, job skill, and "healthy worker" selection were considered as sources of selection biases. More than one third of the eligible subjects at plants 1 and 4 declined to take part in the study. Because subjects at plant 1 were volunteers, prob- 
ably the more interested or better informed individuals participated. Other than age and sex (which were unrevealing), additional data were not available to investigate whether health or exposure related factors influenced self selection. Twenty of the 30 non-respondants at plant 4 were interviewed; 12 did not cite a specific reason for nonparticipation and five said that they were "too busy." These data are insufficient to rule out the possibility of a bias due to non-response.

Since skilled work may develop cognitive function $^{30}$ and since people with superior abilities may select skilled trades, job skill has been identified as a potential confounder in other neurobehavioural studies. ${ }^{81231}$ Pressmen at plant 4 , who were the exposed group, were among the most highly skilled workers in this study. Nevertheless, multiple linear regression analyses gave essentially the same results whether pressmen were included or excluded. This suggests that some other factor operating among printing plant workers may be associated with improved performance. Similarly, Iregren observed that printers surpassed spray painters and nonexposed controls in several cognitive abilities. ${ }^{9}$

Cross sectional studies are vulnerable to an underestimation of risk because affected individuals leave the workplace or select out of exposed jobs within the workplace (healthy worker selection). This has been asserted in several investigations of behavioural effects and documented in one study. ${ }^{32}$ It is not known whether the population in the present study underwent this type of selection. Many of the exposed jobs in the study were high paying, high seniority jobs. Moreover, the small difference between duration of the current job (6 years) and total employment at the plant ( 7 years) suggests that migration between jobs was not a significant factor.

A second limitation of cross sectional studies is inherent in the study design; subjects were not followed up over time and it is not known whether performance deteriorated over time beyond that attributable to the normal aging process.

Current solvent levels are unlikely to have misrepresented current or past exposures. Duration of employment on the current job was relatively short and nearly as long as total duration of employment. Also the plants were relatively new, having been opened in the 1960 s and 1970 s. Leaded paints were infrequently used; moreover, lead would have contributed to an association of adverse solvent related effects, rather than masked it. Other neurotoxic exposures are unlikely to have been overlooked.

Physiological tolerance to short term exposures to solvent has been postulated by Savolainen et al. ${ }^{33}$ Although tolerance to ethanol is widely recognised, tolerance to isopropanol has not been widely studied but would have tended to mitigate the effects of exposures at plant 4 .

Through the consent procedure subjects were informed that the focus of the study was to examine the possible effects of solvents. Compared with the exposed, the non-exposed may have been less motivated, believing that their participation was secondary. The lower response rate of the non-exposed (table 2) suggests that this may have occurred, and the small systematic differences between the exposed and the non-exposed could reflect differences in motivation.

In conclusion, this investigation has not provided evidence of adverse behavioural effects related to exposure to moderately low levels of solvent mixtures for a relatively short duration. Concern over adverse effects of longer term, low level exposure to solvent cannot be completely deferred because of limitations in the study design. Periodic monitoring of workplace solvent exposures and behavioural performance may provide longitudinal data on which to base definitive conclusions.

This project was supported by a contract from the National Institute for Occupational Safety \& Health, United States Department of Health and Human Services.

Requests for reprints to: Dr L J Fine, Room 6007, SPH-II, University of Michigan, Ann Arbor, MI 48109, USA.

\section{References}

' Johnson BL, Anger K. Behavioural toxicology. In: Rom WN, ed. Environmental and occupational medicine. Boston: Little Brown and Company, 1983.

2 Xintaras C, Johnson BL, deGroot I, eds. Behavioural toxicology. Washington DC: US GPO, 1984. (NIOSH publ No 74-126.)

${ }^{3}$ Cherry N, Waldron HA, eds. The neuropsychological effects of solvent exposure. New Lane, England: Colt Foundation, 1983.

4 Cherry N, Waldron HA, Wells GG, Wilkinson RT, Wilson HK. An investigation of the acute behavioural effects of styrene on factory workers. $\mathrm{Br} J$ Ind Med 1980;37:234-40.

s Gamberale F. Behavioural effects of exposure to solvent vapors: experimental and field investigations. In: Horvath $M$, ed. Adverse effects of environmental chemicals and psychotropic drugs. Amsterdam: Elsevier, 1972.

- Gamberale F, Hultengren M. Toluene exposure II. Psychophysiologic functions. Work Environ Health 1972;9:131-9.

' Elofsson S, Gamberale F, Hindmarsh T, et al. Exposure to organic solvents: a cross-sectional epidemiological investigation of occupationally exposed car and industrial spray painters with special reference to the nervous system. Scand J Work Environ Health 1980;6:239-72.

${ }^{8}$ Hanninen H, Eskelinen L, Husman K, Nurminen M. Behavioral effects of long-term exposure to a mixture of organic solvents. Scand J Work Environ Health 1976;4:240-55.

- Iregren A. Effects on psychological test performance of workers exposed to a single solvent (toluene): a comparison with effects of exposure to a mixture of organic solvents. Neurobehav Toxicol Teratol 1982;4:695-701. 
${ }^{10}$ Olson BA. Effects of organic solvents on behavioural performance of workers in the paint industry. Neurobehav Toxicol Teratol 1982;4:703-8.

" Hane M, Axelson O, Blume J, Hogstedt C, Sundell L, Yterborg B. Psychological function changes among house painters. Scand J Work Environ Health 1977;3:91-9.

12 Knave B, Persson HE, Goldberg JM, Westerholm P. Long-term exposure to jet fuel. An investigation on occupationally exposed workers with special reference to the nervous system II. Scand J Work Environ Health 1978;5:19-44.

${ }^{13}$ Hill AB. The environment and disease: association or causation? Proceedings of the Royal Society of Medicine 1965;58:295300.

14 Albers JW, Cavender GD, Levine S, Langold GD. Asymptomatic sensorimotor polyneuropathy in workers exposed to elemental mercury. Neurology 1982;32:1168-74.

is Fitts $P$. The information capacity of the human motor system in controlling the amplitude of movement. J Exp Psychol 1954;47:381-91.

${ }^{16}$ Langolf GD, Chaffin DB, Foulke JA. An investigation of Fitts law using a wide range of movement amplitudes. Journal of Motor Behaviour 1976;8:113-28.

${ }^{17}$ Stroop JR. Studies of interference in serial verbal reactions. J Exp Psychol 1935;18:643-61.

18 Jensen A, Rohmer W. The Stroop color-word test: a review. Acta Psychol 1966;25:36-93.

19 Cooper LA, Sbepard RN. Chronometric studies of the rotation of mental images. In: Chase WG, ed. Visual information processing. New York: Academic Press, 1973.

${ }^{20}$ Sternberg S. Memory scanning: new findings and current controversies. $Q J$ Exp Psychol 1975;27:1-32.

2' Smith PJ, Langolf GD. The use of Sternberg's memory scanning paradigm in assessing the effects of chemical exposure. Human
Factors 1981;23:701-8.

22 Wickelgren WA. Age and storage dynamics in continuous recognition memory. Developmental Psychology 1975;11:165-9.

${ }^{23}$ Smith PJ, Langolf GD, Goldberg J. Effects of occupational exposure to mercury on short term memory. $\mathrm{Br} J$ Ind Med 1983;40:413-9.

24 Whitehead LW, Ball G, Fine LJ, Langolf GD. Am Ind Hyg Assoc $J$ (in press).

${ }^{25}$ Axelson O, Hane M, Hogstedt C. Current aspects of solventrelated disorders. In: Zenz C, ed. Developments in occupational medicine. Chicago: Year Book Publishers, Inc, 1980.

${ }^{26}$ Schumacher J. Effects of aging on four behavioral tests. Ann Arbor, University of Michigan, Center for Ergonomics, 1981.

${ }^{27}$ Maccoby EE, Jacklin CN. The psychology of sex differences. Stanford: Stanford University Press, 1974.

${ }^{28}$ Draper NR, Smith H. Applied regression analysis. New York: John Wiley \& Sons, Inc, 1966.

29 Wechsler D. The measurement and appraisal of adult intelligence. Baltimore: Williams \& Wilkins Co, 1958.

${ }^{30}$ Kohn ML, Schooler CL. Work and personality. Norwood, NJ: Ablex, 1983.

${ }^{31}$ Gregersen P, Stigby B. Reaction time of industrial workers exposed to organic solvents: relationship to degree of exposure and psychologic performance. Am J Ind Med 1981;2:313-21.

${ }^{32}$ Husman K. Symptoms of car painters with long term exposure to a mixture of organic solvents. Scand J Work Environ Health 1980;6:19-32.

${ }^{33}$ Savolainen K, Riihimaki V, Linnoila M. Effects of short-term xylene exposure on psychologic functions in man. Arch Occup Environ Health 1979;44:201-11.

34 American Conference of Governmental Industrial Hygienists. TLVs: threshold limit values for chemical substances and physical agents in the work environment. Cincinnati: ACGIH, 1982.

\section{Destruction of manuscripts}

From 1 July 1985 articles submitted for publication will not be returned. Authors whose papers are rejected will be advised of the decision and the manuscripts will be kept under security for three months to deal with any inquiries and then destroyed. 